\title{
Catabolite repression of dra-nupC-pdp operon expression in Bacillus subtilis
}

\author{
Xianmin Zeng, ${ }^{1}$ Anne Galinier ${ }^{2}$ and Hans H. Saxild ${ }^{1}$ \\ Author for correspondence: Hans H. Saxild. Tel: +45 2524 95. Fax: +45882660. \\ e-mail:imhhs@pop.dtu.dk
}

\begin{abstract}
1 Department of Microbiology, Technical University of Denmark, Building 301, DK-2800 Lyngby, Denmark

2 Institut de Biologie et Chimie des Protéines, CNRS, 7 Passage du Vercors, F-69376 Lyon, Cedex 07, France
\end{abstract}

\begin{abstract}
Expression of the Bacillus subtilis dra-nupC-pdp operon is subject to catabolite repression by glucose. It was shown that a cis-acting catabolite-responsive element (CRE) sequence located 64 bp downstream of the transcription-start site mediated catabolite repression of the dra-nupC-pdp operon as it does for many other B. subtilis genes. Point mutations in the CRE sequence caused the loss of catabolite repression of the operon. Catabolite repression of dra-nupC-pdp expression was relieved in a ccpA mutant and was found to be dependent on both HPr and the HPr-like protein Crh. Furthermore, a transcription-repair coupling factor, Mfd, was also found to be involved in the glucose repression of dra-nupC-pdp expression. By the use of in vitro gel mobility shift analysis, a specific HPr-P dependent binding of CcpA to the dra CRE site was demonstrated.
\end{abstract}

Keywords: Glucose catabolite repression, nucleoside catabolism, $d r a-n u p C-p d p$ operon, Bacillus subtilis, CRE

\section{INTRODUCTION}

Catabolite repression is a general regulatory mechanism of gene expression in response to the availability of carbohydrates in the growth medium. In the presence of a rapidly metabolized carbon source, the synthesis of enzymes involved in the utilization of other carbohydrates is inhibited.

Recent publications present evidence that catabolite repression in Bacillus subtilis involves transcriptional repression mediated by a negative-control system (Hueck \& Hillen, 1995; Saier et al., 1996). Three components are found to be involved in this process: a cis-acting sequence called the catabolite-responsive element (CRE), a trans-acting factor called catabolite control protein A (CcpA), which is a member of the LacI-GalR family of transcription regulatory proteins, and a second trans-acting factor $\mathrm{HPr}$, which is a component of the phosphoenolpyruvate-carbohydrate phosphotransferase system. The HPr protein of $B$. subtilis can be phosphorylated at two sites: one at His15 by enzyme I of the phosphotransferase system and the other at Ser-46 by an ATP-dependent protein kinase. Resistance to glucose repression in strains carrying the

Abbreviations: $C R E$, catabolite-responsive element; $O_{\text {deoR, }}$ DeoR operator.
ptsH1 mutation, which changes the Ser-46 residue of HPr to alanine and thereby prevents phosphorylation of the protein by the ATP-dependent protein kinase, has been reported for several catabolite-repressed genes (Deutscher et al., 1994; Kruger et al., 1996; MartinVerstraete et al., 1995). A homologue of HPr encoded by the crh gene has been reported also to be involved in catabolite repression of inositol dehydrogenase, levanase and $\beta$-xylosidase expression (Galinier et al., 1997). The seryl-phosphorylated Crh protein has a similar function to P-Ser-HPr; it induces the binding of CcpA to CRE sequences (Martin-Verstraete et al., 1999; Galinier et al., 1999).

It is suggested that catabolite repression of target genes in Gram-positive bacteria is achieved by the following mechanism: the metabolite-activated $\mathrm{HPr}(\mathrm{ser})$ kinase phosphorylates Ser-46 in HPr, converting it to a form that can bind to the transcription factor, CcpA. These two proteins, probably together with a metabolite such as fructose 1,6-bisphosphate, form a complex, which binds to CREs of catabolite-sensitive target genes to promote catabolite repression (Deutscher et al., 1995; Fujita et al., 1995). But the finding of P-Ser-HPr independent binding of CcpA complexed with glucose 6-phosphate leads to the proposal that P-Ser-HPr triggers non-cooperative binding of CcpA to CRE sequences, whereas glucose 6-phosphate activates cooperative binding of CcpA to CRE sequences (Fujita et 
Table 1. Bacterial strains and plasmids

\begin{tabular}{|c|c|c|}
\hline Strain/plasmid & Characteristics* & Reference/source \\
\hline \multicolumn{3}{|c|}{ B. subtilis strains } \\
\hline 168 & $\operatorname{trp} C 2$ & C. Anagnostopoulos $†$ \\
\hline QB5407 & $\operatorname{trpC2}$ ccpA:: Tn917 $\Delta($ lacZ-erm $)$ spc & J. Stülkeł \\
\hline QB5223 & trpC2 ptsH1 & Martin-Verstraete et al. (1995) \\
\hline QB7096 & $\operatorname{trp} C 2$ crh::aphA3 & I. Martin-Verstraete $\mathbb{}$ \\
\hline $\mathrm{SF} 22 \mathrm{CDH}$ & $\operatorname{trp} C 2 m f d 22:: \operatorname{Tn} 10$ & Zalieckas et al. (1998b) \\
\hline XM15 & $\operatorname{trp} C 2$ amyE::dra-lacZ (pJOY5) & Zeng \& Saxild (1999) \\
\hline XM45 & $\operatorname{trp} C 2$ amyE::dra-lacZ (pJOY5) ccpA:: Tn917, Spc ${ }^{\mathrm{R}}$ & XM15 transformed with QB5407 \\
\hline XM268 & $\operatorname{trp} C 2$ amyE::pDG268 (neo) & 168 transformed with pDG268neo \\
\hline XM512 & $\operatorname{trp} C 2$ amyE::dra-lacZ (pJOY512), $\mathrm{Neo}^{\mathrm{R}}$ & 168 transformed with pJOY512 \\
\hline XM2681 & $\operatorname{trpC2}$ amyE::pDG268 (neo)::pMutin7756 (cre $)($ erm $)$ & XM330 transformed with pMutin7756 \\
\hline XM2683 & $\operatorname{trpC} 2$ amyE::pDG268 (neo)::pMutin7757 (cre57) (erm) & XM330 transformed with pMutin7757 \\
\hline XM5156erm & $\operatorname{trp} C 2$ amyE::dra-lacZ (pJOY5156erm) & 168 transformed with pJOY5156erm \\
\hline XM5156neo & trpC2 amyE::dra-lacZ (pJOY5156neo) & 168 transformed with pJOY5156neo \\
\hline XM5156A & $\begin{array}{l}\operatorname{trpC2} \text { ccpA:: Tn917 } \Delta(\text { lacZ-erm) spc amyE::dra-lacZ } \\
\text { (pJOY5156neo) }\end{array}$ & XM5156neo transformed with QB5407 \\
\hline XM5156C & trpC2 crh::aphA3 amyE::dra-lacZ (pJOY5156erm), $\mathrm{Neo}^{\mathrm{R}}$ & XM5156erm transformed with QB7096 \\
\hline XM5156M & $\operatorname{trpC} 2$ mfd22::Tn10 amyE::dra-lacZ (pJOY5156erm), $\mathrm{Cm}^{\mathrm{R}}$ & XM5156erm transformed with SF22CDH \\
\hline XM5156P & trpC2 ptsH1 amyE::dra-lacZ (pJOY5156erm) & QB5223 transformed with XM5156erm \\
\hline XM5156PC & $\operatorname{trpC} 2$ ptsH1 crb::aphA3 amyE::dra-lacZ (pJOY5156erm), Neo ${ }^{\mathrm{R}}$ & XM5156P transformed with QB7096 \\
\hline XM5157 & $\operatorname{trpC2}$ amyE::dra-lacZ (pJOY5157, cre57), $\mathrm{Neo}^{\mathrm{R}}$ & 168 transformed with pJOY5157 \\
\hline XM5158 & $\operatorname{trpC2}$ amyE::dra-lacZ (pJOY5158, cre58), $\mathrm{Neo}^{\mathrm{R}}$ & 168 transformed with pJOY5158 \\
\hline XM5158A & $\begin{array}{l}\operatorname{trpC2} \text { ccpA:: Tn917 } \Delta(\text { lacZ-erm) spc amyE::dra-lacZ } \\
\text { (pJOY5158, cre58) }\end{array}$ & XM5158 transformed with QB5407 \\
\hline XM5161 & $\operatorname{trp} C 2$ amyE::dra-lacZ (pJOY5161, $\Delta c r e), \mathrm{Neo}^{\mathrm{R}}$ & 168 transformed with pJOY5161 \\
\hline XM5161A & $\begin{array}{l}\operatorname{trpC2} \text { ccp A:: Tn917 } \Delta(\text { lacZ-erm) spc amyE::dra-lacZ } \\
\text { (pJOY5161, Acre) }\end{array}$ & XM5161 transformed with QB5407 \\
\hline XM7756 & $\operatorname{trpC2}$ amyE::pDG268 (neo):: pMutin7756 (erm) & XM330 transformed with pMutin7756 \\
\hline XM7757 & trpC2 amyE::pDG268 (neo):: pMutin7757 (erm) & XM330 transformed with pMutin7757 \\
\hline \multicolumn{3}{|l|}{ E. coli strains } \\
\hline MC1061 & $\begin{array}{l}\mathrm{F}^{-} \text {araD139 } \Delta(\text { ara-leu }) 7696 \text { galE15 galK16 } \Delta(\text { lac }) X 74 \text { rpsI }\left(\text { Str }^{\mathrm{R}}\right) \\
\text { hsdR2 }\left(\mathrm{r}^{-} \mathrm{m}^{-}\right) \text {mcrA mcrB }\end{array}$ & Laboratory stock \\
\hline \multicolumn{3}{|c|}{ 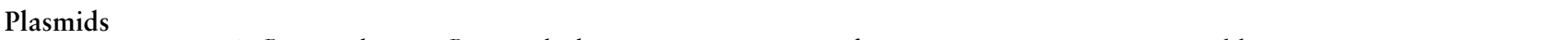 } \\
\hline pDG268neo & $\begin{array}{l}\operatorname{Ap}^{\mathrm{R}}(E . \text { coli }), \mathrm{Neo}^{\mathrm{R}} \text { (B. subtilis); integration vector for } \\
\text { construction of transcriptional lac } Z \text { fusion integrated into the } \\
\text { amyE gene of B. subtilis }\end{array}$ & Zeng \& Saxild (1999) \\
\hline pDG268erm & $\begin{array}{l}\operatorname{Ap}^{\mathrm{R}}\left(\text { E. coli), Er }{ }^{\mathrm{R}} \text { (B. subtilis); integration vector for construction }\right. \\
\text { of transcriptional lacZ fusion integrated into the amyE gene of } \\
\text { B. subtilis }\end{array}$ & Zeng \& Saxild (1999) \\
\hline pMutin4 & $\begin{array}{l}\operatorname{Ap}^{\mathrm{R}}\left(\text { E. coli), } \mathrm{Er}^{\mathrm{R}} \text { (B. subtilis); integrational vector for knockout }\right. \\
\text { mutations and formation of transcriptional lac } Z \text { fusions; the } \\
\text { IPTG-inducible } \mathrm{P}_{\text {spac }} \text { promoter is introduced to ensure expression } \\
\text { of downstream genes }\end{array}$ & Vagner et al. (1998) \\
\hline pJOY512 & $\begin{array}{l}\text { EcoRI-BamHI PCR fragment generated by using primers } 1 \text { and } 2 \text {, } \\
\text { ligated to pDG268neo digested with EcoRI/Bam HI }\end{array}$ & This work \\
\hline pJOY5156erm & $\begin{array}{l}\text { EcoRI-BamHI PCR fragment generated by using primers } 2 \text { and } 3 \text {, } \\
\text { ligated to pDG268erm digested with EcoRI/BamHI }\end{array}$ & This work \\
\hline pJOY5156neo & $\begin{array}{l}\text { EcoRI-BamHI PCR fragment generated by using primers } 2 \text { and } 3 \text {, } \\
\text { ligated to pDG268neo digested with EcoRI/Bam HI }\end{array}$ & This work \\
\hline pJOY5157 & $\begin{array}{l}\text { EcoRI-BamHI PCR fragment generated by using primers } 2 \text { and } 6 \text {, } \\
\text { ligated to pDG268neo digested with EcoRI/Bam HI }\end{array}$ & This work \\
\hline pJOY5158 & $\begin{array}{l}\text { EcoRI-BamHI PCR fragment generated by using primers } 2 \text { and } 7 \text {, } \\
\text { ligated to pDG268neo digested with EcoRI/Bam HI }\end{array}$ & This work \\
\hline pJOY5161 & $\begin{array}{l}\text { EcoRI-BamHI PCR fragment generated by using primers } 2 \text { and } 4 \text {, } \\
\text { ligated to pDG268neo digested with EcoRI/Bam HI }\end{array}$ & This work \\
\hline pMutin7756 & $\begin{array}{l}\text { EcoRI-BamHI PCR fragment generated by using primers } 5 \text { and } 3 \text {, } \\
\text { ligated to pMutin } 4 \text { digested with EcoRI/BamHI }\end{array}$ & This work \\
\hline pMutin7757 & $\begin{array}{l}\text { EcoRI-BamHI PCR fragment generated by using primers } 5 \text { and } 6 \text {, } \\
\text { ligated to pMutin } 4 \text { digested with EcoRI/Bam HI }\end{array}$ & This work \\
\hline pHH1011 & $\begin{array}{l}\text { Plasmid containing a } 760 \mathrm{bp} \text { PvuII-HinclI fragment containing the } \\
3^{\prime} \text { end of } d e o R \text { and the } 5^{\prime} \text { end of } d r a\end{array}$ & Saxild et al. (1996) \\
\hline
\end{tabular}

*Ap, ampicillin; Cm, chloramphenicol; Neo, neomycin; Er, erythromycin; Spc, spectinomycin.

† CNRS, Jouy-en-Josas, France.

‡Universität Erlangen, Erlangen, Germany.

\Institut Pasteur, Paris, France. 
al., 1995; Gösseringer et al., 1997; Miwa et al., 1997; Zalieckas et al., 1998b). However, cofactorindependent sequence-specific DNA binding by CcpA has also been reported (Kim et al., 1995).

Recently, in B. subtilis, several other factors such as CcpB (Chauvaux et al., 1998), CcpC (Jourlin-Castelli et al., 2000), Crh (Galinier et al., 1997), and a transcriptionrepair coupling factor, Mfd (Zalieckas et al., 1998b), have been reported to be involved in catabolite repression. CcpB, which exhibits $30 \%$ sequence identity to CcpA, is found to mediate catabolite repression of gnt and $x y l$ in cells grown on solid medium or in liquid medium with little agitation (Chauvaux et al., 1998). CcpC, which belongs to the LysR family of transcriptional regulators was found to participate in carbon repression of citB (Jourlin-Castelli et al., 2000). Crh, which exhibits $45 \%$ sequence identity to $\mathrm{HPr}$, is not phosphorylated by phosphoenolpyruvate and enzyme I, but is phosphorylated by ATP and the HPr kinase at Ser46 and it is required for catabolite repression of certain catabolite operons (Galinier et al., 1997). The Mfd protein, encoded by $m f d$, is known to promote strandspecific DNA repair by displacing RNA polymerase stalled at a nucleotide lesion and directing the (A)BC excinuclease to the DNA damage site. Resistance towards glucose repression in an $m f d$ mutant has been reported for catabolite-repressed genes containing the CRE sequence located downstream of the transcriptionstart site (Zalieckas et al., 1998b). A model for how catabolite repression is relieved in an $m f d$ mutant was proposed by Zalieckas et al. (1998b). The Mfd protein is proposed to displace RNA polymerase stalled at downstream CRE sites that function as transcription road blocks. The $m f d$ mutation relieves catabolite repression of hut and gnt expression at the CRE sequences located downstream of the transcriptional start sites, but does not affect catabolite repressiom at sites located at the promoters (Zalieckas et al., 1998b).

In B. subtilis, three enzymes required for the utilization of deoxyribonucleosides as carbon sources are encoded within an operon, dra-nupC-pdp (Saxild et al., 1996). The expression of the operon is induced by deoxyribonucleosides and deoxyribose (Saxild et al., 1996; Zeng \& Saxild, 1999). Transcription of this operon is negatively regulated by the DeoR repressor protein encoded by the gene deoR (Saxild et al., 1996). The operator for DeoR contains a palindromic sequence and a direct repeat sequence to the $3^{\prime}$ half of the palindrome located from -58 to $-20 \mathrm{bp}$ relative to the transcription-start point (Zeng \& Saxild, 1999). The metabolite deoxyribose 5phosphate is suggested to be the internal inducer for the expression of the operon (Zeng \& Saxild, 1999; Zeng et al., 2000).

Expression of the $d r a-n u p C-p d p$ operon is repressed by glucose. A CRE sequence located in the start of $d r a$ was found to be involved in catabolite repression of the operon (Zeng \& Saxild, 1999). In this study, we show that CcpA-mediated catabolite repression of the operon works via this downstream CRE sequence and that $\mathrm{HPr}$, $\mathrm{Crh}$ and Mfd participate in catabolite control of $d r a-n u p C-p d p$ operon expression.

\section{METHODS}

Bacterial strains, plasmids and media. The bacterial strains and plasmids used in this work are listed in Table 1. B. subtilis was grown in Spizizen minimal salts medium (Saxild et al., 1996) supplemented with $50 \mu \mathrm{g}$ L-tryptophan $\mathrm{ml}^{-1}$ and with either $0.4 \%$ glucose or $0.4 \%$ succinate as the carbon source. $\mathrm{L}$ broth (Difco) was used as a rich medium for both Escherichia coli and B. subtilis. Culturing of cells was performed at $37^{\circ} \mathrm{C}$. For selection of antibiotic resistance, antibiotics were used at the following final concentrations: ampicillin, $100 \mu \mathrm{g} \mathrm{ml} l^{-1}$; chloramphenicol, $6 \mu \mathrm{g} \mathrm{m} l^{-1}$; neomycin, $5 \mu \mathrm{g} \mathrm{ml}^{-1}$; erythromycin, $1 \mu \mathrm{g} \mathrm{ml}{ }^{-1}$; lincomycin, $25 \mu \mathrm{g} \mathrm{ml}^{-1}$; spectinomycin, $100 \mu \mathrm{g} \mathrm{ml}^{-1}$.

DNA manipulations and genetic techniques. B. subtilis chromosomal DNA and plasmid DNA was isolated as described previously (Saxild et al., 1996). Transformation of E. coli and B. subtilis was performed as previously described (Saxild et al., 1996). Treatment of DNA with restriction enzymes and T4 DNA ligase was performed as recommended by the supplier. DNA sequences were obtained using the Amersham Pharmacia Biotech Thermo Sequenase radiolabelled termination cycle sequencing kit. All sequencing analysis was done on double-stranded plasmid or PCR product DNA templates and performed as described by the supplier. Standard PCR reactions were performed as described previously (Zeng \& Saxild, 1999).

Construction of dra-lacz fusions. Different deletion derivatives of the dra control region were amplified by PCR using plasmid pHH1011, which contains the $3^{\prime}$ end of deoR and the $5^{\prime}$ end of $d r a$, as template DNA (Zeng \& Saxild, 1999). The forward and reverse oligonucleotide primers were synthesized with an EcoRI and BamHI 5'-linked restriction site, respectively (Table 2). The various dra DNA fragments used for the construction of $d r a-l a c Z$ fusions were amplified with primer 2 together with one of the primers $1,3,6,7$ or 4 . The PCR products were digested with EcoRI/BamHI, ligated to EcoRI/BamHI-digested plasmid pDG268erm or pDG268neo and transformed into E. coli MC1061 selecting for ampicillin resistance. Plasmids extracted from E. coli (pJOY512, pJOY5156erm, pJOY5156neo, pJOY5157, pJOY5158 and pJOY5161; Table 1) were linearized by KpnI and recombined into the amyE locus of B. subtilis 168 by transformation and selection for neomycin resistance. The correct integration into the amyE locus was confirmed by the amylase-negative phenotype of the transformants. The resulting B. subtilis strains were XM512, XM5156erm, XM5156neo, XM5157, XM5158 and XM5161 (Table 1).

Construction of $\mathbf{P}_{\text {spac }}$-lac $\boldsymbol{Z}$ fusions. Two $71 \mathrm{bp}$ PCR products amplified by primers $5+3$ and $5+6$, containing the $d r a$ ribosome-binding site and either wild-type or mutant CRE sequence of $d r a$, were cloned in the EcoRI and BamHI sites of pMutin4. The resulting plasmids, pMutin7756 and pMutin7757, were transformed into E. coli MC1061 selecting for ampicillin resistance. Plasmids extracted from E. coli were transformed into XM268 (which contains a promoterless lacZ gene integrated in the amyE locus) by a single crossover between the two copies of lacZ following selection for erythromycin resistance. The correct integration into the lac $Z$ 
Table 2. Oligonucleotides used for PCR amplifications

\begin{tabular}{|c|c|c|c|}
\hline $\begin{array}{l}\text { Primer } \\
\text { name }\end{array}$ & $\begin{array}{l}\text { Linked } \\
\text { restriction } \\
\quad \text { site }\end{array}$ & Sequence $\left(5^{\prime}-3^{\prime}\right)^{*}$ & Coordinates $\dagger$ \\
\hline \multicolumn{4}{|c|}{ Deletion analysis } \\
\hline 1 & $5^{\prime} \mathrm{BamHI}$ & GCGGGATCCCCATGTCGGATTGACAC & +154 \\
\hline 2 & $5^{\prime}$ EcoRI & GCCGGAATTCCCAATTTACATATGTTCAAAAG & -40 \\
\hline 3 & $5^{\prime} \mathrm{BamHI}$ & GCGGGATCCTTGTGTATGCGGTTTCAAAGC & +81 \\
\hline 4 & $5^{\prime} \mathrm{BamHI}$ & GCGGGATCCAAGCTGTATGATCAATTA & +64 \\
\hline 5 & $5^{\prime}$ EcoRI & GCCGGAATTCCAAAAAAGGAAGTGTGCG & +11 \\
\hline \multicolumn{4}{|c|}{ Site-directed mutagenesis } \\
\hline 6 & $5^{\prime} \mathrm{BamHI}$ & GCGGGATCCTTGTGTATGAGGTTTCAAAGC & +81 \\
\hline 7 & $5^{\prime} \mathrm{BamHI}$ & GCGGGATCCTTGTGTATGCAGTTTCAAAGC & +81 \\
\hline \multicolumn{4}{|c|}{ Mobility-shift assay } \\
\hline 8 & $5^{\prime}$ EcoRI & GCCGGAATTCCCTTTCATTGAACAAAATTTC & -66 \\
\hline 9 & $5^{\prime}$ EcoRI & GCCGGAATTCCCTTTCATCGAACAAAATTTC & -66 \\
\hline
\end{tabular}

*Underlined letters indicate the position of the restriction site sequence. Bold letters indicate nucleotides that differ from the wild-type sequence.

† The number indicates the position of the $5^{\prime}$ proximal nucleotide of the primer relative to the $d r a$ transcription-start site (Zeng \& Saxild, 1999). The transcription-start point is genome nucleotide number 4051089 (Kunst et al., 1997).

gene located at the amyE locus of XM268 was confirmed by direct DNA sequencing of specific PCR products from the transformants covering the flanking regions of the lac $Z$ gene. The resulting B. subtilis strains were XM2681 and XM2683 (Table 1).

Site-directed mutagenesis. This was performed by using oligonucleotides with a single mismatch as PCR primers. The primer sequences are shown in Table 2. A standard PCR reaction was performed with one of these primers together with primer 2 . The resulting $122 \mathrm{bp}$ PCR products were cloned into pDG268neo and transformed into B. subtilis as described above. The resulting strains are listed in Table 1.

$\boldsymbol{\beta}$-Galactosidase assay. $\beta$-Galactosidase activity was measured according to the method of Miller (1972). Specific enzyme activities are expressed as $\mathrm{U}(\mathrm{mg} \text { protein })^{-1}$. One unit is defined as $1 \mathrm{nmol}$ substrate converted $\mathrm{min}^{-1}$. The presented values are means of at least three different experiments. The variation was less than $15 \%$. Total protein concentration was determined by the Lowry method.

Mobility-shift assay. The standard PCR mixture containing $25 \mu \mathrm{mol}\left[\alpha^{-33} \mathrm{P}\right] \mathrm{dATP}(25 \mu \mathrm{Ci})$ was used to produce the radiolabelled operator-containing DNA probes. The $148 \mathrm{bp}$ labelled fragments were generated by combining primers $8+3$ and $9+3$. Each binding reaction mixture contained $10 \mathrm{mM}$ Tris/ $\mathrm{HCl}, 50 \mathrm{mM} \mathrm{NaCl}, 1 \mathrm{mM}$ EDTA, $1 \mathrm{mM}$ DTT (pH 7·5), $1 \mathrm{U} \mathrm{ml}^{-1}$ double-stranded poly $(\mathrm{dI}-\mathrm{dC}), 250 \mu \mathrm{g} \mathrm{BSA} \mathrm{ml} \mathrm{m}^{-1}$ and $5 \%(\mathrm{v} / \mathrm{v})$ glycerol in a final volume of $10 \mu \mathrm{l}$. Approximately 10-100 pM labelled DNA probe and various concentrations of proteins were used in each binding reaction. After incubation for $20 \mathrm{~min}$ at room temperature, samples were loaded onto a $5 \%$ polyacrylamide gel and electrophoresed at $7 \mathrm{~V} \mathrm{~cm}^{-1}$ for $1 \mathrm{~h}$. Dried gels were visualized with a Packard Instant Imager. CcpA and HPr proteins were both purified on Ni-nitrilotriacetate-agarose columns (Galinier et al., 1998). HPr was phosphorylated by HprK in the presence of ATP as described by Galinier et al. (1998).

\section{RESULTS}

\section{Localization of the dra-nupC-pdp CRE site using deletion analysis and site-directed mutagenesis}

A set of dra-lac $Z$ transcriptional fusions was constructed for deletion analysis of the catabolite control region of the $d r a-n u p C-p d p$ operon. These fusions were introduced into the amyE locus on the chromosome in a single copy as described in Methods. The upstream end point of all the fusions was at position -40 relative to the transcription-start site and therefore the fusions do not include the DeoR operator $\left(\mathrm{O}_{\text {deoR }}\right)$ site. The positions of the downstream end points were different and are given in Table 3. Catabolite repression of these fusions was monitored during growth in media containing either glucose or succinate as the carbon source (Table 3). The $\beta$-galactosidase activity in strains containing a dra-lacZ fusion including the potential CRE sequence (XM512 and XM5156neo) was repressed approximately fivefold in glucose-grown cells compared to succinate-grown cells, whereas no glucose repression was observed in strains containing a dra-lacZ fusion not including the CRE sequence (XM5161). Point mutations were introduced into the CRE sequence by site-directed mutagenesis. Two mutant strains, XM5157 and XM5158, each having a single-base-pair mutation in the central conserved $\mathrm{C}$ or $\mathrm{G}$ residue of the CRE sequence, were constructed and $\beta$-galactosidase activity was assayed after growth in minimal media with either glucose or succinate as the carbon source. The introduction of a point mutation in strains XM5157 and XM5158 reduced the level of regulation to only $1 \cdot 2$ - and 1.4-fold, respectively. This should be compared to the $5 \cdot 4$-fold repression in the comparable wild-type strain 
Table 3. $\beta$-galactosidase activity of $B$. subtilis strains carrying various dra-lac $Z$ fusions integrated into the amyE locus in the wild-type and different genetic backgrounds

Cells were grown in minimal medium supplemented with either glucose or succinate as the carbon source. Cells were collected and assayed for $\beta$-galactosidase activity as described in Methods. Deoxyribose (dRib; where used) was added to a final concentration of $1 \mathrm{mg} \mathrm{ml}^{-1}$.

\begin{tabular}{|c|c|c|c|c|c|c|c|}
\hline \multirow[t]{2}{*}{ Strain } & \multirow[t]{2}{*}{$\begin{array}{l}\text { Relevant } \\
\text { genotype }\end{array}$} & \multirow[t]{2}{*}{$\begin{array}{l}\text { Region fused } \\
\quad \text { to } \operatorname{lac} Z\end{array}$} & \multirow[t]{2}{*}{$\begin{array}{l}\mathrm{O}_{\text {deoR }} \\
\text { status }\end{array}$} & \multirow[t]{2}{*}{$\begin{array}{l}\text { CRE } \\
\text { status* }\end{array}$} & \multirow[t]{2}{*}{$\begin{array}{l}\text { Inducer } \\
\text { added }\end{array}$} & \multicolumn{2}{|c|}{$\begin{array}{l}\beta \text {-Galactosidase activity } \\
\text { with carbon source: }\end{array}$} \\
\hline & & & & & & Succinate & Glucose $\neq$ \\
\hline XM512 & Wild-type & -40 to +154 & - & + & None & 146 & $34(4 \cdot 3)$ \\
\hline XM5156neo & Wild-type & -40 to +81 & - & + & None & 151 & $28(5 \cdot 4)$ \\
\hline XM5161 & scre & -40 to +64 & - & - & None & 189 & $186(1 \cdot 0)$ \\
\hline XM5157 & cre57 & -40 to +81 & - & Mut & None & 120 & $101(1 \cdot 2)$ \\
\hline XM5158 & cre 58 & -40 to +81 & - & Mut & None & 147 & $102(1 \cdot 4)$ \\
\hline \multirow[t]{2}{*}{ XM15 } & Wild-type & -80 to +154 & + & + & None & 22 & $30(0 \cdot 7)$ \\
\hline & & & & & dRib & 248 & $36(6 \cdot 8)$ \\
\hline \multirow[t]{2}{*}{ XM45 } & $\operatorname{ccp} A$ & -80 to +154 & + & + & None & 27 & $24(1 \cdot 1)$ \\
\hline & & & & & dRib & 190 & $253(0 \cdot 7)$ \\
\hline XM5156A & $c c p A$ & -40 to +81 & - & + & None & 149 & $116(1 \cdot 3)$ \\
\hline XM5161A & ccpA $\Delta$ cre & -40 to +64 & - & - & None & 164 & $159(1 \cdot 0)$ \\
\hline XM5158A & cсpA cre58 & -40 to +81 & - & Mut & None & 158 & $162(1 \cdot 0)$ \\
\hline XM5156P & ptsH1 & -40 to +81 & - & + & None & 163 & $73(1.9)$ \\
\hline XM5156C & $c r h$ & -40 to +81 & - & + & None & 170 & $34(5 \cdot 1)$ \\
\hline XM5156PC & ptsH1 crh & -40 to +81 & - & + & None & 183 & $152(1 \cdot 2)$ \\
\hline XM5156M & $m f d$ & -40 to +81 & - & + & None & 203 & $79(2 \cdot 5)$ \\
\hline
\end{tabular}

* Mut indicates that the CRE element contains either the cre 57 or cre 58 point mutation described in Methods.

† nmol $\min ^{-1}$ (mg protein $)^{-1}$.

‡ Numbers in parentheses indicate level (fold) of repression and were calculated by dividing the enzyme activity in succinate-grown cells by the enzyme activity in glucose-grown cells.

XM5156neo. These results indicated that catabolite repression of $d r a-n u p C-p d p$ expression is mediated by the CRE sequence located at position +64 . Inspection of the nucleotide sequence and additional deletion analysis revealed no other potential CRE elements in the region from position -80 to +154 (data not shown). We therefore conclude that the B. subtilis dra-nupC$p d p$ operon most likely carries a single cis-acting CRE sequence at position +64 relative to the transcriptionstart site.

To investigate whether DeoR affected catabolite repression control at the dra CRE site a lacZ fusion including $\mathrm{O}_{\text {deoR }}$ was constructed (XM15). It was observed that dra expression was not totally repressed during growth on glucose in the absence of deoxyribose. The level of $20-30 \mathrm{U}$ (mg protein $)^{-1}$ of $\beta$-galactosidase activity seen in non-induced strains growing on glucose is significantly higher than in a wild-type strain containing no dra-lacZ fusion [approximately $1 \mathrm{U}$ (mg protein $)^{-1}$ (data not shown)]. In the absence of inducer, that is when the fusion is repressed by DeoR, it appears that there is no catabolite control of $d r a$ expression (XM15, Table 3). One explanation for this phenomenon could be that some minimum number of transcription complexes arriving at the CRE site is required for catabolite repression to operate. This hypothesis was tested using two transcriptional fusions between the IPTG-inducible promoter, $\mathrm{P}_{\text {spac }}$, and lacZ. These fusions, which contain neither the dra promoter nor $\mathrm{O}_{\text {deoR }}$, are composed of a $71 \mathrm{bp}$ fragment containing the wild-type or mutant CRE sequence of $d r a$ inserted between the $\mathrm{P}_{\text {spac }}$ promoter and lacZ, respectively (see Methods). Expression of $\beta$-galactosidase from these fusions as regulated by catabolite repression was monitored during growth in media containing either glucose or succinate as the carbon source. We found that catabolite repression was observed at all levels of IPTG tested up to $1 \mathrm{mM}$ in the fusion strain containing the wild-type CRE, whereas no repression was observed in the fusion strain carrying the mutant CRE (data not shown). This indicated that catabolite control was turned on even at very low transcription-initiation frequencies and did not require some minimum amount of transcription dosage for normal function.

\section{Role of CcpA and the effect of the ptsH1, crh and mfd mutations on dra-nupC-pdp expression}

A $\operatorname{ccp} A$ gene-disruption mutation was introduced into strains XM5156neo and XM5161. XM5156neo and XM5161 carry a transcriptional dra-lacZ fusion with or 
without CRE, respectively. $\beta$-Galactosidase activity was measured for the ccpA derivatives XM5156A and XM5161A grown either in glucose or succinate (Table $3)$. It was shown that glucose repression was almost completely relieved in a $c c p A$ genetic background containing a dra-lac $Z$ fusion either with or without the CRE sequence. The level in succinate-grown cells was unchanged while the level in glucose was increased compared to the wild-type derivatives grown under the same conditions. Essentially the same effect was observed when the cre58 allele was substituted for $\Delta$ cre in the ccpA genetic background (XM5158A). To test whether the glucose catabolite repressor protein CcpA in some way affected the observed constitutively low level of $d r a$ expression in the absence of the inducer deoxyribose (see previous paragraph), a ccpA derivative of XM15 (containing the dra-lacZ fusion including the $\mathrm{O}_{\text {Deor }}$ sequence) was constructed (XM45) and analysed for dra expression during growth with glucose or succinate. The $d r a$ expression level in strain XM45 during growth on glucose, in the absence of deoxyribose, was similar to that of the wild-type, which means that the low level of $d r a$ expression is not a result of the action of CcpA. On the other hand, in the presence of inducer, high constitutive levels were found in both glucose- and succinate-grown cells, indicating that CcpA is involved in catabolite control of $d r a$ expression, at least under induced conditions. All the results presented above indicate that $\mathrm{CcpA}$ is responsible for the glucose control of the $d r a-n u p C-p d p$ operon expression.

To study whether HPr and Crh play a role in catabolite repression of the $d r a-n u p C-p d p$ operon, a $p t s H 1$ mutation was introduced into strain XM5156erm carrying a transcriptional dra-lacZ fusion, resulting in strain XM5156P. Similarly, a crh gene disruption mutation (Galinier et al., 1997) was introduced into XM5156erm resulting in XM5156C. The $\beta$-galactosidase activity of both glucose- and succinate-grown cells was measured for these two strains (Table 3). Glucose repression was partially relieved resulting in a reduction to $1 \cdot 9$-fold of regulation in the $p t s H 1$ mutant, while disruption of the $c r h$ gene in the wild-type background did not alter the pattern of catabolite repression of the operon expression. However, disruption of the crh gene in the ptsH1 background (XM5156PC) almost totally abolished catabolite repression. These results suggested that, in addition to $\mathrm{HPr}$, which plays the major role in signalling the presence of glucose to CcpA, Crh also participated in catabolite repression of the $d r a-n u p C-p d p$ operon as it does for other B. subtilis catabolite-repressed genes such as lev and xyn (Martin-Verstraete et al., 1999; Galinier et al., 1999). To investigate the role of Mfd in catabolite repression of $d r a-n u p C-p d p$ operon expression, an $m f d:$ Tn10 mutation was introduced into XM5156erm resulting in strain XM5156M, and $\beta$-galactosidase activity was measured in both glucose- and succinategrown cells (Table 3 ). The results showed that the glucose repression was only $2 \cdot 5$-fold in the $m f d$ mutant compared to $5 \cdot 4$-fold in the wild-type cells. This result

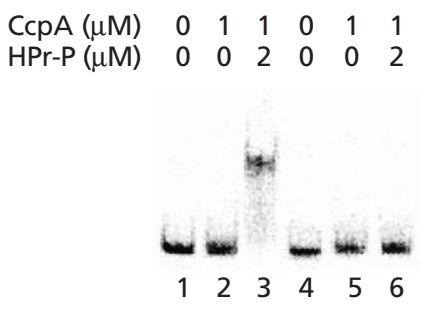

Fig. 1. Binding of $C c p A$ to the $C R E$ of the dra-nupC-pdp operon. A profile of a mobility-shift assay is shown. DNA fragments containing either the wild-type cre (lanes 1-3) or the mutant cre57 element (lanes 4-6) were incubated with various combinations of CcpA and P-Ser-HPr.

was similar to what has been observed for the expression of the hut and gnt operons in an $m f d$ genetic background (Zalieckas et al., 1998b). So CcpA most likely mediates catabolite repression of $d r a$ expression via the binding to a single downstream CRE, thus functioning by a transcriptional road-block mechanism.

\section{Specific interaction between CcpA and CRE}

The presumed interaction between CcpA and the CRE of the $d r a-n u p C-p d p$ operon was demonstrated by an in vitro gel mobility-shift experiment. The DNA probes were two $\left[{ }^{33} \mathrm{P}\right]$-labelled $148 \mathrm{bp}$ fragments containing either the wild-type CRE sequence or the mutant CRE sequence with an A substituted for the central C (cre57). As shown in Fig. 1, the mobility of the labelled DNA containing the wild-type CRE was shifted in the presence of CcpA and P-Ser-HPr, but no shift was observed for the DNA with the mutant CRE. When CcpA was present alone in the assay, no interaction was observed (Fig. 1, lane 2); only in the presence of P-Ser-HPr did CcpA specifically recognize the CRE (Fig. 1, lane 3). The results presented in Fig. 1 clearly demonstrate the specific P-Ser-HPr dependent binding of CcpA to the dra CRE site. The results complement the previous genetic data obtained using lac $Z$ fusions and various regulatory mutations (Table 3).

\section{DISCUSSION}

By the use of both genetic and biochemical means we have demonstrated that the B. subtilis dra-nupC-pdp operon carries a downstream CRE sequence that is involved in CcpA-mediated catabolite repression. Moreover, $\mathrm{HPr}$, Crh and Mfd were proved to participate in catabolite repression of the operon expression. The pattern of catabolite repression of the $d r a-n u p C-p d p$ operon provides us with a fine example in which all the factors found to be involved in the negative-control system of catabolite repression in B. subtilis play a role in catabolite control of this operon.

An interesting aspect of our study is that catabolite repression of the $d r a-n u p C-p d p$ operon is absent when the expression is repressed by the DeoR repressor. Only in a $d e o R$ strain or in a wild-type strain induced with deoxyribose (Zeng \& Saxild, 1999) does catabolite 
repression take place. We suggested a mechanism to explain this phenomenon and designed an experiment to test this suggestion. However, the experiment did not confirm that catabolite repression of the $d r a-n u p C-p d p$ operon requires a minimum amount of transcription arriving at the CRE site.

A special feature of the catabolite repression of the $d r a-n u p C-p d p$ operon exerted by DeoR and CcpA is that it is leaky [approximately $20-30 \mathrm{nmol} \mathrm{min}{ }^{-1}$ (mg protein $)^{-1} \beta$-galactosidase activity during the repressed condition (Table 3)]. It means that neither CcpA or DeoR binds sufficiently strongly to their operators to totally prevent transcription initiation (DeoR) or transcription elongation (CcpA). One reason for maintaining a low level of deoxyriboaldolase could be that accumulation of the substrate, deoxyribose 5phosphate, is toxic for the cell (Saxild et al., 1996). Deoxyribose 5-phosphate is produced constitutively at a low level by deoxyribomutase, encoded by $\mathrm{drm}$ (Schuch et al., 1999). Maybe therefore the level of catabolite repression of $d r a-n u p C-p d p$ operon expression is quite low (fivefold) compared to 17-fold for acsA (Zalieckas et al., 1998a), 16-fold for $x y l$ (Gösseringer et al., 1997), 32-fold for lev (Martin-Verstraete et al., 1995) and 25fold for hut (Wray et al., 1994).

The structure with one and only one CRE site located more than $50 \mathrm{nt}$ downstream of the transcription start has also been reported for the xyn gene (Galinier et al., 1999). Even though the xyn gene is repressed approximately 110-fold by glucose (Galinier et al., 1999), the unity and the location of the dra CRE site may account for some of the observed leakiness of the glucose repression of $d r a-n u p C-p d p$ operon expression.

\section{ACKNOWLEDGEMENTS}

We thank Dr I. Martin-Verstraete for providing strains QB5223 and QB7096, and Dr. Susan Fisher for SF22CDH. This research received financial support from the Novo Nordic Foundation and from the Saxild Family Foundation.

\section{REFERENCES}

Chauvaux, S., Paulsen, I. \& Saier, M. H., Jr (1998). CcpB, a novel transcription factor implicated in catabolite repression in Bacillus subtilis. J Bacteriol 180, 491-497.

Deutscher, J., Reizer, J., Fischer, C., Galinier, A., Saier, M. H., Jr \& Steinmetz, M. (1994). Loss of protein kinase-catalyzed phosphorylation of HPr, a phosphocarrier protein of the phosphotransferase system, by mutation of the $p t s H$ gene confers catabolite repression resistance to several catabolite genes of Bacillus subtilis. J Bacteriol 176, 3336-3344.

Deutscher, J., Kuster, E., Bergstedt, U., Charrier, v. \& Hillen, W. (1995). Protein kinase-dependent HPr/CcpA interaction links glycolytic activity to carbon catabolite repression in gram-positive bacteria. Mol Microbiol 15, 1049-1053.

Fujita, Y., Miwa, Y., Galinier, A. \& Deutscher, J. (1995). Specific recognition of the Bacillus subtilis gnt cis-acting cataboliteresponsive element by a protein complex formed between CcpA and seryl-phosphorylated HPr. Mol Microbiol 17, 953-960.

Galinier, A., Haiech, J., Kilhoffer, M., Jaquinod, M., Stulke, J., Deutscher, J. \& Martin-Verstraete, I. (1997). The Bacillus subtilis crh gene encodes a HPr-like protein involved in carbon catabolite repression. Proc Natl Acad Sci U S A 94, 8439-8444.

Galinier, A., Kravanja, M., Engelmann, R., Hengstenberg, W., Kilhoffer, M. C., Deutscher, J. \& Haiech, J. (1998). New protein kinase and protein phosphatase families mediate signal transduction in bacterial carbon catabolite repression. Proc Natl Acad Sci U S A 95, 1823-1828.

Galinier, A., Deutscher J. \& Martin-Verstraete, I. (1999). Phosphorylation of either Crh or HPr allows binding of CcpA to the Bacillus subtilis xyn catabolite responsive element. J Mol Biol 286, 307-314.

Gösseringer, R., Kuster, E. E., Galinier, A., Deutscher, J. \& Hillen, W. (1997). Cooperative and non-cooperative DNA binding modes of catabolite control protein CcpA from Bacillus megaterium result from sensing two different signals. J Mol Biol 266, 665-676.

Hueck, C. J. \& Hillen, W. (1995). Catabolite repression in Bacillus subtilis: a global regulatory mechanism for gram-positive bacteria? Mol Microbiol 15, 395-401.

Jourlin-Castelli, C., Mani, N., Nakano, M. M. \& Sonenshein, A. L. (2000). CcpC, a novel regulator of the LysR family required for glucose repression of the citB gene in Bacillus subtilis. J Mol Biol 295, 865-878.

Kim, J. H., Guvener, Z., Cho, J., Chung, K. \& Chambliss, G. (1995). Specificity of DNA binding activity of the Bacillus subtilis catabolite control protein CcpA. J Bacteriol 177, 5129-5134.

Kruger, S., Gertz, S. \& Hecker, M. (1996). Transcriptional analysis of $b g l P H$ expression in Bacillus subtilis: evidence for two distinct pathways mediating carbon catabolite repression. J Bacteriol 17, 2637-2644.

Kunst, F., Ogasawara, N., Moszer, I. \& 148 other authors (1997). The complete genome sequence of the Gram-positive bacterium Bacillus subtilis. Nature 390, 249-256.

Martin-Verstraete, I., Stukle, J., Klier, A. \& Rapoport, G. (1995). Two different mechanisms mediate catabolite repression of the Bacillus subtilis levanase operon. J Bacteriol 177, 6919-6927.

Martin-Verstraete, I., Deutscher, J. \& Galinier, A. (1999). Phosphorylation of HPr and Crh by HprK, early steps in the catabolite repression signalling pathway for the Bacillus subtilis levanase operon. J Bacteriol 181, 2966-2969.

Miller, J. H. (1972). Assay of $\beta$-galactosidase. In Experiments in Molecular Genetics, pp. 352-355. Edited by J. H. Miller. Cold Spring Harbor, NY: Cold Spring Harbor Laboratory.

Miwa, Y., Nagura, K., Eguchi, S., Fukuda, H., Deutscher, J. \& Fujita, Y. (1997). Catabolite repression of the Bacillus subtilis gut operon exerted by two catabolite-responsive elements. Mol Microbiol 23, 1203-1213.

Saier, M. H., Jr, Chauvaux, S., Cook, G. M., Deutscher, J., Paulsen, I. T., Reizer, J. \& Ye, J.-J. (1996). Catabolite repression and inducer control in Gram-positive bacteria. Microbiology 142, 217-230.

Saxild, H. H., Andersen, L. N. \& Hammer, K. (1996). Dra-nupC$p d p$ operon of Bacillus subtilis : nucleotide sequence, induction by deoxyribonucleosides, and transcriptional regulation by the deoR-encoded DeoR repressor protein. J Bacteriol 178, 424-434.

Schuch, R., Garibian, A., Saxild, H. H., Piggot, P. J. \& Nygaard, P. (1999). Nucleosides as a carbon source in Bacillus subtilis: characterization of the $d r m-p u p G$ operon. Microbiology 145, 2957-2966.

Vagner, V., Dervyn, E. \& Ehrlich, S. D. (1998). A vector for systematic gene inactivation in Bacillus subtilis. Microbiology 144, 3097-3104.

Wray, L. V., Pettengill, F. \& Fisher, S. H. (1994). Catabolite repression of the Bacillus subtilis hut operon requires a cis-acting 
site located downstream of the transcription initiation site. $J$ Bacteriol 176, 1894-1902.

Zalieckas, J. M., Wray, L. V. \& Fisher, S. H. (1998a). Expression of the Bacillus subtilis acs $A$ gene: position and sequence context affect cre-mediated carbon catabolite repression. J Bacteriol 180, 6649-6654.

Zalieckas, J. M., Wray, L. V., Ferson, A. \& Fisher, S. H. (1998b). Transcription-repair coupling factor is involved in carbon catabolite repression of the Bacillus subtilis hut and gnt operons. Mol Microbiol 27, 1031-1038.
Zeng, X. \& Saxild, H. H. (1999). Identification and characterization of a DeoR specific operator sequence essential for induction of the dra-nupC-pdp operon expression in Bacillus subtilis. J Bacteriol 181, 1719-1727.

Zeng, X., Saxild, H. H. \& Switzer, R. L. (2000). Purification and characterization of the DeoR repressor of Bacillus subtilis. J Bacteriol 182, 1916-1922.

Received 28 March 2000; revised 6 July 2000; accepted 25 July 2000. 